\title{
MODELL ALAPÚ PREDIKTÍV IRÁNYÍTÁSI ALGORITMUS, ÁLLAPOTFÜGGŐ RICCATI-EGYENLET, ILLETVE VÉGES HORIZONTÚ DLQR ALGORITMUSOK ÖSSZEHASONLÍTÁSA
}

\section{COMPARISONS BETWEEN APPLIED MODEL PREDICTIVE CONTROL, STATE DEPENDENT RICCATI EQUATION, AND FINITE HORIZON DISCRETE OPTIMAL CONTROL ALGORITHMS}

\author{
Dávid László ${ }^{1}$, György Katalin ${ }^{2}$, Kelemen András ${ }^{3}$ \\ ${ }^{1,2,3}$ Sapientia-Erdélyi Magyar Tudományegyetem, Müszaki és Humántudományok \\ Kar, Villamosmérnöki Tanszék, Románia, 540485 Târgu Mureş, O.p. 9, C.p. 4., Te- \\ lefon / Fax: +40-265-206210, \\ ldavid@ms.sapientia.ro; kgyorgy@ms.sapientia.ro; kandras@ms.sapientia.ro
}

\begin{abstract}
The model predictive control (MPC) - also called receding horizon control (RHC or RHMPC) - is a widely used control method, where the control input is obtained by solving a discrete-time optimal control problem over a finite horizon. According to this control strategy only the first value from the computed control sequence is applied. At the next sampling instant, a new optimal control problem is formulated and solved based on the new measurements. While the theory of MPC for linear systems is well developed, regarding the analysis of stability, feasibility, optimality and robustness, nowadays research focuses on problems which tipically require significant computation effort- more specifically the attention in practice is driven by the fact that processes are nonlinear and need to be operated under restricted conditions. Often these demands can be satisfied when process nonlinearities and constraints are explicitly considered in the controller algorithm. In this article the nonlinear optimal control is reviewed, based on the state dependent Riccati equations, MPC and RHC. The most important disadvantages and some of the computational aspects are also proven. Furthermore, in order to facilitate the analysis of stability and dynamic behavior, we have proven that the receding finite horizon LQR and MPC are similar, but they are considerably different from the infinite horizon SDRE.
\end{abstract}

Keywords: $L Q R$, receding horizon control, model predictive control, state dependent Riccati equation

\section{Összefoglalás}

A modell alapú prediktív szabályozások (MPC), amelyeket sok esetben csúszó horizontú irányításként (RHC vagy RHMPC) ismer a szakirodalom, egy széles körben használatos modern irányítási módszert jelentenek, ahol a vezérlőjel szekvenciát egy véges horizonton meghatározott diszkrét idő-optimum feladat megoldásaként fogalmazzuk meg. Ez a stratégia a kiszámított vezérlőjel szekvencia első tagját használja fel, míg a következő lépésekben az új mérésekre alapozva újraszámítjuk a vezérlőjelet. Bár a lineáris MPC (RHMPC) elmélete jól kidolgozott, és ez több területre is kiterjed, mint a stabilitás, megvalósíthatóság, optimalitás, illetve robusztusság, napjainkban gyakorlatilag a nemlineáris, szigorú megszorításokkal müködő folyamatokra vonatkozó feladatok váltak érdekessé. Ezeket csak akkor lehet megfelelő módon figyelembe venni, ha a folyamat nemlinearitásait, illetve a megszorításokat explicit módon kezeljük az irányítási algoritmus levezetésénél. A cikkben áttekintjük az nemlineáris 
folyamatok irányításának tervezését állapotfüggő Riccati-egyenletek segítségével, hibaforrásait és hátrányait, valamint az elméleti számítási kérdéseket. Továbbá, mivel erős korlátok esetében a végtelen horizontú megközelítés helyett a véges horizontú irányítást kell alkalmaznunk, ez újabb hibákat, esetleg instabilitást eredményez. Ezek vizsgálatának megkönnyítése érdekében a diszkrét lineáris véges horizontú kvadratikus szabályozásokat (LQR) összehasonlítottuk a nem korlátos modell alapú prediktív szabályozásokkal (MPC).

Kulcsszavak: LQR, csúszó horizontú irányitás, modell prediktív irányítás, állapotfüggő Riccati-egyenlet

\section{Bevezetés}

Az ipari szabályozástechnikában az elmúlt évtizedekben viharos gyorsasággal terjedt el egy olyan módszer, amelynek elméleti háttere nem túlságosan bonyolult, és elegáns, tudományosan megalapozott megoldást kínál a gyakorlati irányítási feladatok többségére. Kiindulópontjának a klasszikus optimális irányításelméletet tekinthetjük, amelynek gyakorlati alkalmazását jelentősen korlátozza a bemenetek, az állapotok, illetve kimenetek pontos korlátozásának lehetősége, valamint a pontatlan modell és a zajos környezetben elvárt robusztus viselkedés. Ezt a módszert modell alapú prediktív irányításnak (MPC) vagy más néven csúszó horizontú irányításnak (RHC vagy RHMPC) nevezzük, amelynek elmélete jelentős kutatások témakörét képezte az elmúlt két évtizedben. A szabványos MPC irányítás olyan optimális irányítási feladatokat old meg, amelyek esetében minden mintavételre meghatározzuk a célfüggvény minimumát biztosító ún. optimális vezérlőjel szekvenciát, majd az így származtatott szekvenciából, mint egy nyílthurkú optimális irányítási algoritmusból, úgy származtatjuk az aktuális irányítást, hogy csak a szekvencia első értékét használjuk az aktuális irányításhoz. Ezután minden új mintavételi időpontban az elcsúsztatott horizontra vonatkoztatva újraszámítjuk az optimális vezérlőjel szekvenciát. Ezért a véges horizontú MPC tervezése során nincs mód a zárt rendszer tulajdonságainak pontos tervezésére, de ugyanakkor, ha a célfüggvény paramétereit (súlyzók értéke, modell, illetve irányítási horizont értéke stb.) próbálgatással változtatjuk, szinte mindig lehetséges elfogadható müködést beállítani. Mindezek alapján minden mintavételben szükségszerüen meg kell oldanunk egy a horizonttól függő, korlátos optimumkeresési feladatot.

A modell-prediktív irányítási algoritmusok egy speciális osztályát jelentik a csúszó horizontú irányításoknak, amelyek esetében a perdikciós horizont az idővel együtt mozog. Ezt a technikát talán a legegyszerübb állapotteres modellre megfogalmazni, ezért sokszor nem is az MPC, hanem az RHC rövidítéssel utalnak rá, és az alkalmazott modell sem átviteli függvény alapú. Az állapotteres megfogalmazás további előnye, hogy mind lineáris változó paraméterü, mind pedig az alábbi cikkben tárgyalt nemlineáris rendszerekre is alkalmazható. A megközelítés további előnye pedig az, hogy képes korlátozásokat kezelni mind az állapottérben, mind pedig a kimenetet befolyásoló zaj tekintetében.

A legnagyobb gondot az jelenti, hogy a véges horizontra megfogalmazott MPC nem garantálja mindig a zárthurkú irányított rendszer stabilitását [1], amint az a végtelen horizontra megfogalmazott klasszikus LQ irányításnál következett, az algebrai Riccati-egyenlet megoldása segítségével kapott vezérlőjel szekvenciából.

Dolgozatunkban megvizsgáltuk a nemlineáris folyamatok szuboptimális irányítási algoritmusának hibaforrásait, valamint azt, hogy a véges csúszó horizontra megfogalmazott MPC, illetve DLQR módszerek mennyiben térnek el a végtelen horizontra 
számított irányítástól. Mindkét módszert ugyanazon rendszerosztályra - lineáris, időinvariáns állapotteres modellre és négyzetes célfüggvényre - alkalmaztuk. Egy külön fejezetben a szakaszos szaggatott LQ követő szabályozásokat hasonlítjuk össze az MPC technikával. A két módszer összehasonlítása kapcsán azok azonosságát$N=1,2$ horizontra általánosan, hosszabb horizontra szimulációval - bizonyítottuk.

\section{Nemlineáris rendszerek LQR- SDRE irányítása}

Ismert tény, hogy a Hamilton-Jacobielmélet egyik fontos alkalmazása a lineáris rendszerek négyzetes célfüggvény segítségével való optimális szabályozása. Bár első látásra ez a megszorítás jelentösen csökkenti a tanulmányozott módszer általánosságát, két érvet szokás felsorakoztatni mellette. Egyfelöl a lineáris rendszerek optimális irányítása kapcsolatot teremt a klasszikus szabályozáselmélet módszerei, valamint a MIMO rendszerek állapotteres irányítási technikái között, így ezek matematikai értelmezését biztosíthatják az amúgy empirikus módszereknek. Másfelöl napjainkban mindinkább teret hódít a nemlineáris rendszerek ún. szuboptimális irányítása, amelyet számos esetben lineáris technikák általánosításával kapunk meg. Ilyen például a linearizálási technikák alkalmazhatóságát jelentősen kibővítő állapotfüggő Riccatiegyenleten alapuló módszer [2] (SDRE State Dependent Riccati Equation).

Optimális állapotszabályozáson a dinamikus rendszert leíró állapotegyenleteknek megfelelö, $\underline{u}^{*}(t)$ optimális vezérlőjel meghatározását értjük, amely biztosítja valamely $J(\underline{u})$ célfüggvény minimumát.

$$
\begin{aligned}
& \frac{d}{d t} \underline{x}(t)=\boldsymbol{f}(\underline{x}(t), \underline{u}(t), t) \\
& \underline{y}(t)=\boldsymbol{g}(\underline{x}(t), \underline{u}(t), t)
\end{aligned}
$$

Általános esetben megjegyezhetjük, hogy mivel a szabályozó struktúrája nem előre rögzített, ezért előállhatnak olyan helyzetek, amikor az $\underline{u}^{*}(t)$ optimális vezérlőjel gyakorlatilag nem valósítható meg, esetleg nem egyértelmü. Általában a lineáris feladatot az $\underline{x}(t)$ állapotvektor és $\underline{u}(t)$ vezérlőjel vektora, az $\underline{y}(t)$ kimeneti vektor által meghatározott lineáris rendszer állapotegyenletei:

$$
\begin{aligned}
& \frac{d}{d t} \underline{x}(t)=\boldsymbol{A}(t) \cdot \underline{x}(t)+\boldsymbol{B}(t) \cdot \underline{u}(t) \\
& \underline{y}(t)=\boldsymbol{C}(t) \cdot \underline{u}(t)
\end{aligned}
$$

valamint a véges horizontú négyzetes célfüggvény határozzák meg, amelynek a minimumát keressük:

$$
\begin{aligned}
& J(\underline{u})=\frac{1}{2}\langle x(t f), \boldsymbol{F} x(t f)\rangle+\ldots \\
& +\frac{1}{2} \int_{t_{0}}^{t f}[\langle\underline{x}(\tau), \boldsymbol{Q}(\tau) \underline{x}(\tau)\rangle+\langle\underline{u}(\tau), \boldsymbol{R}(\tau) \underline{u}(\tau)\rangle] \cdot d \tau
\end{aligned}
$$

ahol $\langle.,$.$\rangle a skaláris szorzatot jelképező$ szimbólum, $\boldsymbol{Q}(t), \boldsymbol{F}$ pozitív szemidefinit súlyzómátrixok, az $\boldsymbol{R}(t)$ pozitív súlyzómátrix és végül $t_{0} t_{f}$ a kezdeti-, valamint a végállapothoz rendelt időpillanat. Felírva a Hamilton-függvényt és az ennek megfelelő Hamilton-Jacobi-egyenleteket, meghatározható az optimális szabályozási jel, mint:

$$
\underline{u}^{*}(t)=-\boldsymbol{R}(\mathrm{t})^{-1} \cdot \boldsymbol{B}(\mathrm{t})^{T} \cdot \boldsymbol{P}(\mathrm{t}) \cdot \underline{x}(t)
$$

ahol a $\boldsymbol{P}(t)$ egy Riccati típusú mátrix differenciálegyenlet (5) megoldása:

$$
\begin{aligned}
& \frac{d}{d t} \boldsymbol{P}(t)=-\boldsymbol{P}(t) \cdot \boldsymbol{A}(t)-\boldsymbol{A}(t)^{T} \cdot \boldsymbol{P}(\boldsymbol{t})+\ldots \\
& +\boldsymbol{P}(t) \cdot \boldsymbol{B}(t) \cdot \boldsymbol{R}(t)^{-1} \cdot \boldsymbol{B}(t)^{T} \cdot \boldsymbol{P}(t)-\boldsymbol{Q}(\boldsymbol{t})
\end{aligned}
$$

amelynek a peremfeltétele: $\boldsymbol{P}\left(t_{f}\right)=\boldsymbol{F}$. 
A (6) optimális pályát a kiszámított optimális vezérlőjel segítségével kapjuk meg,

$$
\underline{\dot{x}}^{*}(t)=\left[\boldsymbol{A}(t)-\boldsymbol{B}(t) \cdot \boldsymbol{R}^{-1}(t) \cdot \boldsymbol{B}^{T}(t) \cdot \boldsymbol{P}(t)\right] \cdot \underline{x}^{*}(t)
$$

ahol ismert az állapotvektor kezdeti értéke:

$$
\underline{x}\left(t_{0}\right)=\underline{x}_{0} .
$$

Végtelen horizont esetén az (5) differenciálegyenlet az ún. algebrai Riccatiegyenletté alakul.

Természetesen feltevődik az a kérdés, hogy miként válasszuk meg az $\boldsymbol{R}$ és $\boldsymbol{Q}$ súlyzómátrixokat, pontosabban milyen öszszefüggés feltételezhető a mátrixok elemei és az állapotvektor, valamint a vezérlőjel nagysága között. Bár ezeknek a korlátozásoknak a pontos elméleti tárgyalását az ún. modell alapú prediktív szabályozásoknál tudjuk elvégezni, jó eredménnyel alkalmazható empirikus összefüggéseket már az 1970-es évektől megfogalmaztak.

A nemlineáris rendszerek optimális szabályozása esetén az a kérdés, hogy kapunk vagy sem olyan gyors valós idejü algoritmust, amely az adott nemlineáris folyamatot képes irányítani, hisz ismert tény, hogy a nemlineáris algoritmusok sokszor iteratív számításokat igényelnek amelyeket, nem lehet valós időben implementálni. Erre jelent egy lehetséges megoldást az állapotfüggő Riccati-egyenlet, hisz alkalmazza a lineáris gyors számítási algoritmusokat.

Tekintsünk egy sajátos nemlineáris rendszert, mint:

$$
\begin{aligned}
& \dot{x}=f(x)+g(x) \cdot u= \\
& =A(x) \cdot x+B(x) \cdot u
\end{aligned}
$$

Közvetlenül is meg lehet próbálni a fent bemutatott, végtelen horizontra vonatkozó optimális szabályozási eljárást, de ez az egyszerüsített megközelítés várhatóan hibaforrást jelent.

Amennyiben a vizsgált rendszer ilyen (8) formára hozható és irányítható, akkor a szabályozójel az ismert,

$$
\underline{u}^{*}(\underline{x})=-\boldsymbol{R}^{-1}(\underline{x}) \cdot \boldsymbol{B}^{T}(\underline{x}) \cdot \boldsymbol{P}(\underline{x}) \cdot \underline{x}(t)
$$

egyenletből számítható. Az állapotfüggőnek tekintett Riccati-mátrixot az állapotfüggő algebrai Riccati egyenletből kapjuk meg, mint:

$$
\begin{aligned}
& \boldsymbol{P}(\underline{x}) \cdot \boldsymbol{A}(\underline{x})+\boldsymbol{A}^{T}(\underline{x}) \cdot \boldsymbol{P}(\underline{x})+\boldsymbol{Q}(\underline{x})-\ldots \\
& -\boldsymbol{P}(\underline{x}) \cdot \boldsymbol{B}(\underline{x}) \cdot \boldsymbol{R}^{-1}(\underline{x}) \cdot \boldsymbol{B}^{T}(\underline{x}) \cdot \boldsymbol{P}(\underline{x})=\mathbf{0}
\end{aligned}
$$

Ebben az esetben az állapotfüggő tulajdonság azt eredményezi, hogy minden állapot környékén újra kell számítani a megoldást, de jelenleg ez nem jelent gondot, mert a folytonos esetben (persze ennek igazából csak elméleti jelentősége van) gyors algoritmusok állnak rendelkezésünkre, mint a Schur-, Potter- vagy Newton-módszer, amelyek akár beágyazott rendszereken is futhatnak. Azt viszont meg kell jegyeznünk, hogy ez az algoritmus csak felületes szemlélő számára jelent optimális irányítást, hisz a szükséges feltételek számítása esetében elhanyagoltuk a rendszermátrixok állapotfüggő tagjainak deriváltjait.

Példaként tekintsük egy egyszerü általános másodfokú rendszert [3]:

$$
\begin{aligned}
& \dot{x}_{1}=f_{1}(\underline{x}) \\
& \dot{x}_{2}=f_{2}(\underline{x})+g(\underline{x}) \cdot u
\end{aligned}
$$

Vagyis:

$$
\frac{d}{d t}\left(\begin{array}{l}
x_{1} \\
x_{2}
\end{array}\right)=\left(\begin{array}{cc}
0 & \frac{f_{1}(\underline{x})}{x_{2}} \\
0 & \frac{f_{2}(\underline{x})}{x_{2}}
\end{array}\right)\left(\begin{array}{l}
x_{1} \\
x_{2}
\end{array}\right)+\left(\begin{array}{c}
0 \\
g(\underline{x})
\end{array}\right) u(12)
$$

Feltételezzük, hogy az $\underline{x}=0$ esetében az $\frac{f_{1}(\underline{x})}{x_{2}}$, illetve $\frac{f_{2}(\underline{x})}{x_{2}}$ jól meghatározottak, pontosabban véges, nullától különböző értékü törtek. Ekkor könnyü belátni, hogy az $x_{1}=0, x_{2}=0$ pont egyensúlyi állapot, mert ekkor $\dot{x}_{1}=0, \dot{x}_{2}=0$. Válasszuk a következő súlyzókat: 
$\boldsymbol{Q}(\underline{x})=\left(\begin{array}{cc}q_{1}(\underline{x}) & 0 \\ 0 & q_{2}(\underline{x})\end{array}\right), R(\underline{x})=r(\underline{x})$,

ahol, $q_{1}(\underline{x})>0, q_{2}(\underline{x})>0, r(\underline{x})>0$.

A szabályozójel meghatározásához írjuk fel a rendszerhez rendelt algebrai Riccatiegyenletet (10). A megfelelő számítások elvégzése után a következő egyenletrendszerhez jutunk:

$$
\left\{\begin{array}{l}
-\frac{p_{12}^{2} g^{2}(\underline{x})}{r(\underline{x})}+q_{1}(\underline{x})=0 \\
p_{11} \frac{f_{1}(\underline{x})}{x_{2}}+p_{12} \frac{f_{2}(\underline{x})}{x_{2}}-\frac{p_{12} p_{22} g^{2}(\underline{x})}{r(\underline{x})}=0 \\
2 p_{12} \frac{f_{1}(\underline{x})}{x_{2}}+2 p_{22} \frac{f_{2}(\underline{x})}{x_{2}}-\frac{p_{22}^{2} g^{2}(\underline{x})}{r(\underline{x})}+q_{2}(\underline{x})=0 .
\end{array}\right.
$$

Innen meghatározhatók a $p_{12}, p_{22}$ értékek, amelyek felhasználásával a vezérlőjel:

$$
u^{*}(\underline{x})=-\frac{1}{r(\underline{x})}\left(p_{12} g(\underline{x}) \quad p_{22} g(\underline{x})\right)\left(\begin{array}{l}
x_{1} \\
x_{2}
\end{array}\right)(15)
$$

A visszacsatolt rendszer állapotmátrixa:

$$
\begin{aligned}
& \boldsymbol{A}_{r}=\left(\begin{array}{ll}
a_{r 11} & a_{r 12} \\
a_{r 21} & a_{r 22}
\end{array}\right), \quad \text { ahol } \\
& a_{r 11}=0, \quad a_{r 12}=\frac{f_{1}(\underline{x})}{x_{2}} \\
& a_{r 21}= \pm g(\underline{x}) \sqrt{\frac{q_{1}(\underline{x})}{r(\underline{x})}} \\
& a_{r 22}= \pm \sqrt{\left(\frac{f_{2}(\underline{x})}{x_{2}}\right)^{2}+\frac{g^{2}(\underline{x}) q_{2}(\underline{x})}{r(x)} \pm 2 \frac{f_{1}(\underline{x}) g(\underline{x})}{x_{2}} \sqrt{\frac{q_{1}(x)}{r(\underline{x})}}} .
\end{aligned}
$$

Ennek sajátértékei meghatározzák a zárt kör satbilitását és dinamikus viselkedését. Mivel a paraméterfüggő állapotmátrix több megválasztása is lehetséges, ezért ennek kiválasztására a rendszer vezérelhetősége jelent támpontot. Az előbbi példánk kapcsán ez a feltétel:

$$
\operatorname{det}\left(\boldsymbol{W}_{C t r}\right)=-g^{2}(\underline{x}) \cdot \frac{f_{1}(\underline{x})}{x_{2}} \neq 0,
$$

ahol:

$$
\begin{aligned}
\boldsymbol{W}_{C t r} & =\left[\begin{array}{ll}
\boldsymbol{B}(\underline{x}) & \boldsymbol{A}(\underline{x}) \boldsymbol{B}(\underline{x})
\end{array}\right]= \\
& =\left[\begin{array}{cc}
0 & \frac{f_{1}(\underline{x})}{x_{2}} g(\underline{x}) \\
g(\underline{x}) & \frac{f_{2}(\underline{x})}{x_{2}} g(\underline{x})
\end{array}\right]
\end{aligned}
$$

A vizsgált példában egyszerüen elhanyagoltuk az állapotfüggö tagok szerepét a módszer bizonyításában, amit a szakma gyakorlatában nagyon sok esetben tapasztalhatunk, ezért a kapott eredmény bizonyos esetben alkalmazhatatlan vagy akár instabil is lehet. Ezért nézzük meg a következőkben, hogy miként módosul az ismert optimum, amennyiben a (2) egyenlethez hasonló állapotfüggő dinamikus rendszer kvadratikus optimumát keressük.

Ennek megoldása érdekében meghatározzuk a következő Hamilton-függvényt:

$$
\begin{aligned}
& H(\underline{x}, \underline{u}, \underline{p}, t)=\frac{1}{2} \underline{x}^{T} \boldsymbol{Q}(\underline{x}) \underline{x}+\frac{1}{2} \underline{u}^{T} \boldsymbol{R}(\underline{x}) \underline{u}+ \\
& +\underline{p}^{T}(A(\underline{x}) \cdot \underline{x}+\boldsymbol{B}(\underline{x}) \cdot \underline{u}) .
\end{aligned}
$$

ahol $\underline{p}(t)=\boldsymbol{P}(\underline{x}, t) \cdot \underline{x}(t)$.

A minimum szükséges feltételei:

$$
\begin{aligned}
& \frac{\partial H}{\partial \underline{u}}=\underline{0} \Rightarrow \\
& \underline{u}^{*}(t)=-\boldsymbol{R}^{-1}(x) \cdot \boldsymbol{B}^{T}(\underline{x}) \cdot \boldsymbol{P}(\underline{x}, t) \cdot \underline{x}(t) \\
& \frac{\partial H}{\partial \underline{p}}=\underline{\dot{x}}(t) \Rightarrow \\
& \underline{\dot{x}}(t)=A(\underline{x}) \cdot \underline{x}(t)+\boldsymbol{B}(\underline{x}) \cdot \underline{u}^{*}(t) \\
& \frac{\partial H}{\partial \underline{x}}=-\underline{\dot{p}} \Rightarrow \underline{\dot{p}}(t)=-\boldsymbol{Q}(\underline{x}) \cdot \underline{x}(t)-. \\
& -\frac{\partial[A(\underline{x}) \underline{x}]}{\partial \underline{x}} \underline{p}(t)-\frac{\partial[B(\underline{x}) \underline{u}]}{\partial \underline{x}} \underline{p}(t) . \\
& \mathrm{A} \frac{\partial[A(\underline{x}) \underline{x}]}{\partial \underline{x}}, \text { illetve } \frac{\partial[B(\underline{x}) \underline{u}]}{\partial \underline{x}} \text { kifejezé- }
\end{aligned}
$$

sek egy-egy négyzetes mátrixot jelentenek, a $\dot{P}(x, t)$ pedig a $P(x, t)$ Riccati-mátrix teljes differenciálja. Behelyettesítve az $\underline{\dot{x}}$, 
illetve a $\underline{\dot{p}}$ kifejezéseit megkapjuk az optimális pálya szükséges feltételét:

$$
\begin{aligned}
& \dot{\mathbf{P}}(\underline{x})=-\mathbf{P}(\underline{x}) \mathbf{A}(\underline{x})+\mathbf{P}(\underline{x}) \mathbf{B}(\underline{x}) \mathbf{R}^{-1} \mathbf{B}^{T}(\underline{x}) \mathbf{P}(x)- \\
& -\mathbf{Q}-\left[\frac{\partial \mathbf{A}(\underline{x})}{\partial \underline{x}} \underline{x}\right] \mathbf{P}(\underline{x})-\mathbf{A}^{T}(\underline{x}) \mathbf{P}(\underline{x})+\frac{\partial[\mathbf{B}(x) \underline{u}]}{\partial \underline{x}} \mathbf{P}(\underline{x})
\end{aligned}
$$

Ahhoz, hogy ez az egyenlet a (10) formájú legyen, szükséges a (24) összefüggés teljesülése.

$$
\dot{\mathbf{P}}(\underline{x})=-\left[\frac{\partial \mathbf{A}(\underline{x})}{\partial \underline{x}} \underline{x}\right] \mathbf{P}(\underline{x})+\frac{\partial[\mathbf{B}(\underline{x}) u]}{\partial \underline{x}} \mathbf{P}(\underline{x})
$$

Mivel ez a feltétel az esetek többségében nem teljesül, ezért ekkor csak szuboptimális tervezésről beszélhetünk. Ennek érzékeltetésére tekintsük az előbbi általános példa egy sajátos esetét:

$$
\begin{aligned}
& \dot{x}_{1}=f_{1}(\underline{x})=\sin x_{1}+x_{2} \\
& \dot{x}_{2}=f_{2}(\underline{x})+g(\underline{x}) \cdot u=x_{1} x_{2}+u
\end{aligned}
$$

Nézzük az állapotfüggő rendszeregyenletek két lehetséges felírását:

$$
\left[\begin{array}{l}
\dot{x}_{1} \\
\dot{x}_{2}
\end{array}\right]=\left[\begin{array}{cc}
\frac{\sin x_{1}}{x_{1}} & 1 \\
0 & x_{1}
\end{array}\right] \cdot\left[\begin{array}{l}
x_{1} \\
x_{2}
\end{array}\right]+\left[\begin{array}{l}
0 \\
1
\end{array}\right] u
$$

vagy

$$
\left[\begin{array}{l}
\dot{x}_{1} \\
\dot{x}_{2}
\end{array}\right]=\left[\begin{array}{cc}
\frac{\sin x_{1}}{x_{1}} & 1 \\
\frac{1}{2} x_{2} & \frac{1}{2} x_{1}
\end{array}\right] \cdot\left[\begin{array}{l}
x_{1} \\
x_{2}
\end{array}\right]+\left[\begin{array}{l}
0 \\
1
\end{array}\right] u
$$

Ellenőrizzük mindkét esetben a irányíthatóságot. Mindkét rendszer irányítható, mert a (28) irányíthatósági mátrixok rangja 2.

$$
\mathbf{W}_{C t r 1}=\left[\begin{array}{cc}
0 & 1 \\
1 & x_{1}
\end{array}\right] \mathbf{W}_{C t r 2}=\left[\begin{array}{cc}
0 & 1 \\
1 & \frac{1}{2} x_{1}
\end{array}\right]
$$

A következőkben felírjuk a végtelen horizontra számított, állapotfüggő Riccati- egyenletet az első változatra. Ennek megoldását a következő egyenletek segítségével kapjuk meg:

$$
\begin{aligned}
& 2 p_{11} \frac{\sin x_{1}}{x_{1}}-\frac{1}{r} p_{12}{ }^{2}+q_{1}=0 \\
& p_{11}+p_{12} x_{1}+p_{12} \frac{\sin x_{1}}{x_{1}}-\frac{1}{r} p_{12} p_{22}=0 \\
& 2 p_{12}+2 p_{22} x_{1}-\frac{1}{r} p_{22}{ }^{2}+q_{2}=0 .
\end{aligned}
$$

A hibák érzékeltetésére megoldjuk a feladatot a Hamilton-Jacobi-módszerrel. A Hamilton-függvény ebben az esetben:

$$
\begin{aligned}
& H(\underline{x}, \underline{u}, \underline{p}, t)=\frac{1}{2} q_{1} x_{1}^{2}+\frac{1}{2} q_{2} x_{2}^{2}+\frac{1}{2} r u^{2}+ \\
& +p_{1}\left(\sin x_{1}+x_{2}\right)+p_{2} x_{1} x_{2}+p_{2} u,
\end{aligned}
$$

ahol a $\mathrm{p}_{1}$ és $\mathrm{p}_{2}$ a $\mathrm{p}$ segédvektor elemei.

Az optimum szükséges (20), (21), (22) feltételei az SDRE által meghatározott öszszefüggés mellett az alábbi (31) összefüggések teljesülését is megkívánják:

$$
\begin{aligned}
& p_{11}\left(\cos x_{1}-\frac{\sin x_{1}}{x_{1}}\right)+p_{12} x_{2}+\dot{p}_{11}=0 \\
& p_{12}\left(\cos x_{1}-\frac{\sin x_{1}}{x_{1}}\right)+p_{22} x_{2}+\dot{p}_{12}=0 .
\end{aligned}
$$

A Riccati-mátrixegyenletből származó négy egyenlet közül kettő megegyezik az SDRE egyenletekkel, kettő pedig korrekciós tagokat is tartalmaz, és amennyiben a szuboptimális megoldásként az SDRE módszert használjuk, akkor számolnunk kell a korrekciós tagok elhanyagolásának perturbáló szerepével. Azt könnyen láthatjuk, hogy az $x_{1}=0, x_{2}=0$ egyensúlyi állapotok közelében a perturbáció hatása elhanyagolható, de az ettől jelentősen eltérő állapotok esetében ez jelentős lehet. Ennek nagyságát mutatjuk be az alábbi ábrákon, ahol a rendszer kezdöállapota $x_{1}=10$ és $x_{2}=10$. Az 1. ábrán az állapotok változása a 2. ábrán pedig az SDRE megoldással kapott Riccati-mátrix elemei, valamint a korrekciós tagok változása látható. 


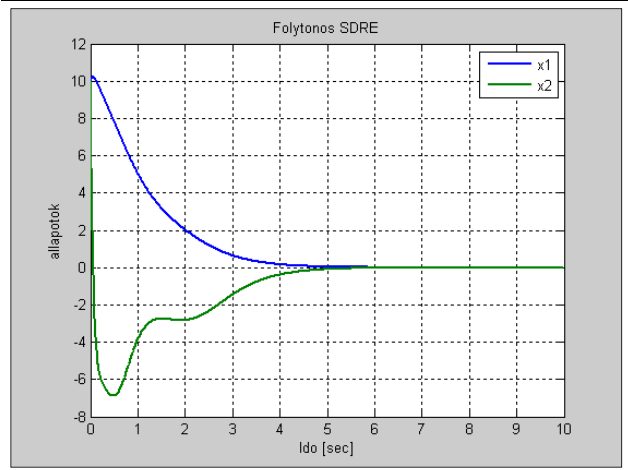

1. ábra Az állapotok időbeli változása

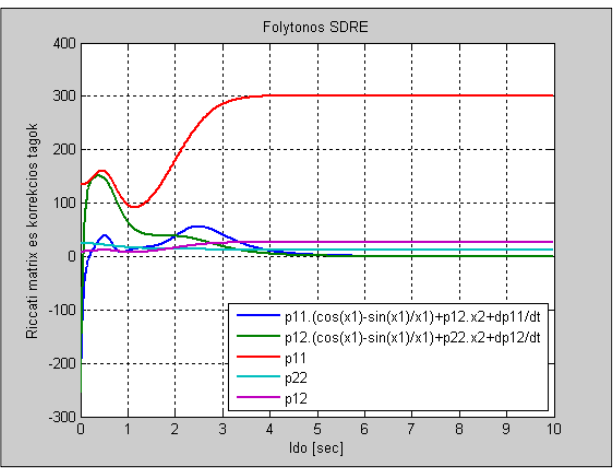

2. ábra $A z S D R E$ megoldással kapott Riccati mátrix elemei, valamint a korrekciós tagok változása

Látható, hogy a korrekciós tagok nagysága - amelyek időben nullához tartanak a kezdetben összemérhetőek a Riccatimátrix elemeivel, ami jelentős hibát, pontosabban dinamikaromlást eredményezhet. Mindezek alapján könnyen belátható, hogy az SDRE nem jelent optimális megoldást, sőt sok esetben annak a kérdése is felmerülhet, hogy a kapott megoldás stabil vagy sem. Ezért több olyan módszert is kidolgoztak, amelyek segítségével valamilyen módon kompenzálni lehessen a fenti perturbációs tagok hatásait. Ilyen módszer lehet az állapotfüggő súlyzómátrixok bevezetése (13), de sajnos ennek még nincs egységes elmélete. Az így tervezett SDRE irányítás stabilitásának szükséges és elégséges feltételeit Cloutier és társai határozták meg [4].

\section{A csúszó horizontú DLQR, illetve a modell alapú prediktív irányí- tás}

A fenti irányítási algoritmusok gyakorlati számítógépes megvalósítása mindig a folyamat szakaszos szaggatott modellje alapján történhet úgy, hogy a folytonos rendszermodellt az ismert munkapont környezetében megközelítjük ennek diszkrét modelljével. Ekkor az optimális irányítási technikák esetében feltételezünk egy véges mozgó horizontot mint az aktuális állapottól számított irányítási horizontot. A diszkrét dinamikus rendszeregyenlet:

$$
\underline{x}_{k+1}=\boldsymbol{\Phi}\left(x_{k}\right) \cdot \underline{x}_{k}+\boldsymbol{\Gamma}\left(x_{k}\right) \cdot \underline{u}_{k},
$$

ahol $\Phi \in \mathbf{R}^{\mathbf{n} \times \mathbf{n}}, \Gamma \in \mathbf{R}^{\mathbf{n} \times \mathbf{p}}$ és $C \in \mathbf{R}^{\mathbf{p} \times \mathbf{n}}$. Illetve a célfüggvény:

$$
\begin{aligned}
& J\left(\underline{x}_{0}, \underline{u}\right)=\frac{1}{2}\left\langle\underline{x}_{N}, \boldsymbol{F} \underline{x}_{N}\right\rangle+ \\
& +\frac{1}{2} \sum_{k=0}^{N-1}\left\langle\underline{x}_{k}, \boldsymbol{Q}_{k} \underline{x}_{k}\right\rangle+\left\langle\underline{u}_{k}, \boldsymbol{R}_{k} \underline{u}_{k}\right\rangle .
\end{aligned}
$$

Az egyszerüség kedvéért bevezetjük a következő jelöléseket az állapotfüggő mátrixokra $\boldsymbol{\Phi}\left(\underline{x}_{k}\right)=\boldsymbol{\Phi}_{k}$, illetve $\boldsymbol{\Gamma}\left(\underline{x}_{k}\right)=\boldsymbol{\Gamma}_{k}$. A Riccati-mátrix meghatározására a következő diszkrét rekurzió alkalmazható [5]:

$$
\begin{aligned}
& \boldsymbol{P}_{k}=\boldsymbol{\Phi}_{k}{ }^{T} \boldsymbol{P}_{k+1} \boldsymbol{\Phi}_{k}+\boldsymbol{Q}_{k}- \\
& \boldsymbol{\Phi}_{k}{ }^{T} \boldsymbol{P}_{k+1} \boldsymbol{\Gamma}_{k}\left(\boldsymbol{R}_{k}+\boldsymbol{\Gamma}_{k}{ }^{T} \boldsymbol{P}_{k+1} \boldsymbol{\Gamma}_{k}\right)^{-1} \boldsymbol{\Gamma}_{k}{ }^{T} \boldsymbol{P}_{k+1} \boldsymbol{\Phi}_{k},
\end{aligned}
$$

ahol a végfeltétel: $\boldsymbol{P}_{N}=\boldsymbol{F}$.

Különösen fontos az LQ optimális irányítás inkrementális algoritmusa, ugyanis a számítógépes szábályozó kimenete egy nulladrendü tartót tartalmaz, ezért minden mintavételben az új vezérlőjelet úgy kapjuk mint:

$$
\underline{u}_{k}=\Delta \underline{u}_{k}+\underline{u}_{k-1},
$$


ahol az $\underline{u}_{k-1}$ a $\left[t_{k-1}, t_{k}\right]$ mintavételi periódusra érvényes vezérlőjel, illetve a $\Delta \underline{u}_{k}$, a $\left[t_{k}, t_{k+1}\right]$ mintavételre számított korrekció. Figyelembe kell venni, hogy a tanulmányozott irányítási algoritmusok esetében nem a vezérlőjel abszolút értékét, hanem ennek változását szokás korlátozni, mert ez határozza meg a rendszer rángásmentes, sima müködését. Feltételezzük, hogy a $\underline{z}_{k}$ elöírt pálya adott különböző $t_{k}$ mintavételezési időpontokban. Így a véges csúszó horizontú irányítás esetében keressük azt az optimális szabályozó jelet, amely biztosítja a következő négyzetes célfüggvény minimumát:

$$
\begin{aligned}
& J\left(\underline{x}_{k}, \underline{u}\right)=\underline{e}_{k+N}^{T} \cdot \boldsymbol{F} \cdot \underline{e}_{k+N}+\ldots \\
& +\sum_{i=0}^{N-1} \underline{e}_{k+i}^{T} \boldsymbol{Q}_{k+i} \cdot \underline{e}_{k+i}+\sum_{i=0}^{N_{c}-1} \Delta \underline{u}_{k+i}^{T} \cdot \boldsymbol{R}_{k+i} \cdot \Delta \underline{u}_{k+i}
\end{aligned}
$$

ahol $\underline{e}_{k+i}$, a $\underline{z}_{k+i}$ elöírt pályának megfelelő követési hiba, $\Delta \underline{u}_{k+i}=\underline{u}_{k+i}-\underline{u}_{k+i-1}$ pedig a vezérlőjel változása. $N$ a predikciós horizontot, míg az $N_{c}$ a szabályozási horizontot jelöli.

A szabályozójel meghatározásának egyszerüsítése érdekében feltételezzük, hogy a két horizont értéke egyenlö. Mivel a célfüggvényben nem a vezérlöjel értéke, hanem ennek változása jelenik meg, a folyamat szakaszos szaggatott modellje vagy az optimumot kifejező egyenlet is ezt kell tartalmazza. A következökben két módszert is alkalmazhatunk ennek kifejezésére. Egyfelől bevezethetünk egy új állapotvektort $\underline{\xi}_{k}=\left[\begin{array}{ll}\underline{x}_{k} & \underline{u}_{k-1}\end{array}\right]^{T}$, amivel a rendszer bemeneteinek és kimeneteinek a száma nem, de az állapotvektor dimenziója $n+m$-re változik. Ezután a folyamatnak megfelelő rendszert a következö új, megnövelt dimenziójú egyenletekkel jellemezhetjük:

$$
\begin{gathered}
\left(\begin{array}{c}
\underline{x}_{k+1} \\
\underline{u}_{k}
\end{array}\right)=\left(\begin{array}{cc}
\boldsymbol{\Phi}_{k} & \boldsymbol{\Gamma}_{k} \\
0 & \mathbf{I}
\end{array}\right) \cdot\left(\begin{array}{c}
\underline{x}_{k} \\
\underline{u}_{k-1}
\end{array}\right)+\left(\begin{array}{c}
\boldsymbol{\Gamma}_{k} \\
\mathbf{I}
\end{array}\right) \cdot \Delta \underline{u}_{k} \Rightarrow \\
\underline{y}_{k}=\left(\begin{array}{ll}
\mathbf{C}_{k} & 0
\end{array}\right) \cdot\left(\begin{array}{c}
\underline{x}_{k} \\
\underline{u}_{k-1}
\end{array}\right) \\
\left\{\begin{array}{l}
\underline{\xi}_{k+1}=\hat{\boldsymbol{\Phi}}_{k} \cdot \underline{\xi}_{k}+\hat{\boldsymbol{\Gamma}}_{k} \cdot \Delta \underline{u}_{k} \\
\underline{y}_{k}=\hat{\mathbf{C}}_{k} \cdot \underline{\xi}_{k}
\end{array}\right.
\end{gathered}
$$

Amennyiben a $\boldsymbol{\Phi}_{k}, \boldsymbol{\Gamma}_{k}, \mathbf{Q}_{k}$ és $\mathbf{R}_{k}$ mátrixok időtől vagy az állapotoktól függnek, akkor a vezérlöjel számítása a folyamat müködése alatt módosul. A szabályozási feladatnak megfelelő Bellmanegyenletet természetesen az elözőkben megnövelt új dimenzióra kell felírni, mint:

$$
\begin{aligned}
& J^{*}\left(\underline{\xi}_{k+i}, \underline{u}\right)=\min _{u_{k+i}}\left\{\underline{\hat{e}}_{k+i}^{T} \cdot \hat{\boldsymbol{Q}}_{i} \cdot \underline{\hat{e}}_{k+i}+\ldots\right. \\
& \left.+\Delta \underline{u}_{k+i}^{T} \cdot \boldsymbol{R}_{i} \cdot \Delta \underline{u}_{k+i}+J^{*}\left(\underline{\xi}_{k+i+1}, \underline{u}\right)\right\},
\end{aligned}
$$

ahol a $J^{*}\left(\underline{\xi}_{k}, \underline{u}\right)$ az $\underline{x}_{k}$ állapotot tartalmazó $\underline{\xi}_{k}$ állapottól a végpontig számított, illetve az $J^{*}\left(\underline{\xi}_{k+1}, \underline{u}\right)$ az $\underline{x}_{k+1}$ állapotot tartalmazó $\underline{\xi}_{k+1}$ állapottól a végpontig számított optimális költségfüggvény. Az $\underline{\hat{e}}_{k}$ és $\hat{\mathbf{Q}}_{k}$ a megnövelt dimenziójú követési hibavektor illetve súlyzómátrix.

Az LQ irányítás paramétereit rekurzívan számolva $i=N, N-1, \ldots, 0$, az optimális vezérlőjel inkrementum meghatározható, mint:

$$
\begin{aligned}
& \Delta \underline{u}_{k+i}{ }^{*}=-\left[\boldsymbol{R}_{i}+\hat{\boldsymbol{\Gamma}}_{k+i}^{T} \cdot \hat{\boldsymbol{P}}_{i+1} \cdot \hat{\boldsymbol{\Gamma}}_{k+i}\right]^{-1} \cdot \ldots \\
& {\left[\boldsymbol{\Gamma}_{k+i}^{T} \cdot \hat{\boldsymbol{P}}_{i+1} \cdot \hat{\boldsymbol{\Phi}}_{k+i} \cdot \underline{\xi}_{k+i}+\frac{1}{2} \cdot \hat{\boldsymbol{\Gamma}}_{k+i}^{T} \cdot \hat{g}_{i+1}\right],}
\end{aligned}
$$

ahol a klasszikus módszert követve a Riccati-egyenletet, illetve a pályakövetést biztositó segédállapot rekurzív egyenletét is a megnövelt dimenzióra kell felírnunk, mint: 
$\hat{\boldsymbol{P}}_{i}=\hat{\boldsymbol{C}}_{k+i}^{T} \hat{\boldsymbol{Q}}_{i} \hat{\boldsymbol{C}}_{k+i} \ldots$

$-\hat{\boldsymbol{\Phi}}_{k+i}^{T} \hat{\boldsymbol{P}}_{i+1} \cdot \hat{\boldsymbol{\Gamma}}_{k+i}\left[\boldsymbol{R}_{i}+\hat{\boldsymbol{\Gamma}}_{k+i}^{T} \hat{\boldsymbol{P}}_{i+1} \cdot \hat{\boldsymbol{\Gamma}}_{k+i}\right]^{-1} \hat{\boldsymbol{\Gamma}}_{k+i}^{T} \hat{\boldsymbol{P}}_{i+1} \hat{\boldsymbol{\Phi}}_{k+i}$

$\ldots+\hat{\boldsymbol{\Phi}}_{k+i}^{T} \hat{\boldsymbol{P}}_{i+1} \hat{\boldsymbol{\Phi}}_{k+i}, \hat{\boldsymbol{P}}_{N}=\hat{\boldsymbol{C}}_{k+N}^{T} \cdot \hat{\boldsymbol{F}} \hat{\boldsymbol{C}}_{k+N}$.

illetve

$\hat{\underline{g}}_{i}=\left[\hat{\boldsymbol{\Phi}}_{k+i}^{T}-\hat{\boldsymbol{\Phi}}_{k+i}^{T} \hat{\boldsymbol{\Gamma}}_{i+1} \hat{\boldsymbol{\Gamma}}_{k+i}\left(\boldsymbol{R}_{i}+\hat{\boldsymbol{\Gamma}}_{k+i}^{T} \hat{\boldsymbol{P}}_{i+1} \hat{\boldsymbol{\Gamma}}_{k+i}\right)^{-1} \hat{\boldsymbol{\Gamma}}_{k+i}^{T}\right] \underline{\underline{g}}_{i+1}-{ }^{-}(41)$

$-2 \hat{\boldsymbol{C}}_{k+1}^{T} \hat{\boldsymbol{Q}}_{i} \hat{\underline{z}}_{k+i}$

$\underline{\hat{g}}_{N}=-2 \cdot \hat{\boldsymbol{C}}_{k+N}^{T} \hat{\boldsymbol{F}} \hat{\underline{z}}_{k+N}$

Alkamazva az előzőkben tárgyalt példára, az alábbi ábrákból könnyen követhető az a dinamikaváltozás, amit a különböző célfüggvények használata eredményez.

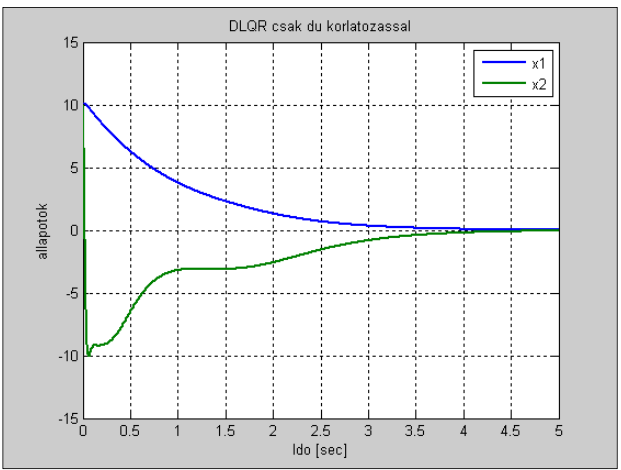

3. ábra $A$ szakaszos szaggatott müködésü irányítás esetén a rendszer állapotainak változása $\Delta u$ korlátozással

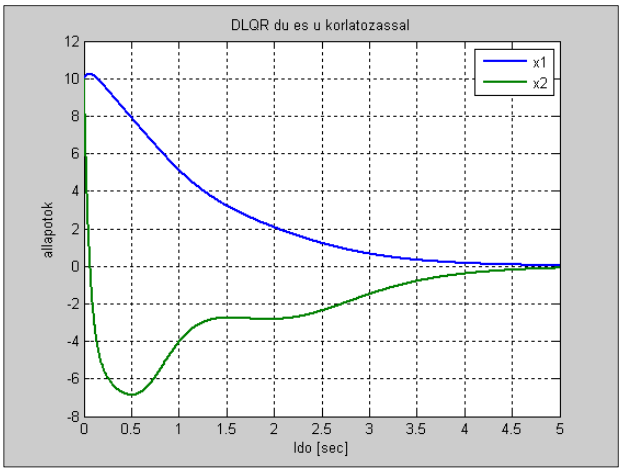

4. ábra A szakaszos szaggatott müködésü irányítás esetén a rendszer állapotainak változása $\Delta u$ és $\underline{u}$ korlátozással
A módszer előnye az, hogy a modell dimenziójának megnövelését követően könnyen alkalmazható a klasszikus DLQR számítási eredménye, hátránya viszont pont a növelt dimenzióból eredő számítási többlet.

Alternatív módszerként átírhatjuk az eredeti modellt, mint:

$$
\begin{aligned}
& \underline{x}_{k+1 / k}=\boldsymbol{\Phi}_{k} \cdot \underline{x}_{k / k}+\boldsymbol{\Gamma}_{k} \cdot \underline{u}_{k / k}= \\
& =\boldsymbol{\Phi}_{k} \cdot \underline{x}_{k / k}+\boldsymbol{\Gamma}_{k} \cdot \Delta \underline{u}_{k / k}+\boldsymbol{\Gamma}_{k} \cdot \underline{u}_{k-1}, \\
& \underline{y}_{k}=\mathbf{C}_{k} \cdot \underline{x}_{k / k}
\end{aligned}
$$

és keressük a szakaszos szaggatott rendszer optimális vezérlőjel-szekvenciáját. Kiinduló pontnak a $t_{k}$ pillanatot tekintjük. Ekkor a rendszerhez rendelt Bellman-egyenletet felírhatjuk, mint:

$$
\begin{aligned}
& J^{*}\left(\underline{x}_{k+i / k}, \underline{u}^{\prime}\right) \min _{\underline{u}_{k+i}}\left\{\underline{e}_{k+i}^{T} \cdot \boldsymbol{Q}_{i} \cdot \underline{e}_{k+i}+\ldots\right. \\
& \left.+\Delta \underline{u}_{k+i / k}^{T} \cdot \boldsymbol{R}_{i} \cdot \Delta \underline{u}_{k+i / k}+J^{*}\left(\underline{x}_{k+i+1 / k}, \underline{u}\right)\right\}
\end{aligned}
$$

Feltételezzük, hogy a célfüggvény optimális értéke a következő alakban írható fel:

$$
J^{*}\left(x_{k+i / k}, \underline{u}\right)=\underline{p}_{i}^{<0>}+\underline{g}_{i}^{T} \cdot \underline{x}_{k+i / k}+\underline{x}_{k+i / k}^{T} \cdot \boldsymbol{P}_{i} \cdot \underline{x}_{k+i / k}
$$

Hasonló gondolatmenetet követve, mint az előbb, az inkrementális LQ irányítás algoritmusa a következő:

$$
\begin{aligned}
& \Delta \underline{u}_{k+i}{ }^{*}=-\left[\boldsymbol{R}_{i}+\boldsymbol{\Gamma}_{k+i}^{T} \cdot \boldsymbol{P}_{i+1} \cdot \boldsymbol{\Gamma}_{k+i}\right]^{-1} \cdot \ldots \\
& \cdot\left[\boldsymbol{\Gamma}_{k+i}^{T} \cdot \boldsymbol{P}_{i+1} \cdot \boldsymbol{\Phi}_{k+i} \cdot \underline{x}_{k+i}+\frac{1}{2} \cdot \boldsymbol{\Gamma}_{k+i}^{T} \cdot \underline{g}_{i+1}+. .\right. \\
& \left..+\boldsymbol{\Gamma}_{k+i}^{T} \cdot \boldsymbol{P}_{i+1} \cdot \boldsymbol{\Gamma}_{k+i} \cdot \underline{u}_{k+i-1}\right] \\
& \boldsymbol{P}_{i}=\boldsymbol{C}_{k+i}^{T} \cdot \boldsymbol{Q}_{i} \cdot \boldsymbol{C}_{k+i}-\boldsymbol{\Phi}_{k+i}^{T} \cdot \boldsymbol{P}_{i+1} \cdot \boldsymbol{\Gamma}_{k+i} \cdot\left[\boldsymbol{R}_{i}+\boldsymbol{\Gamma}_{k+i}^{T} \cdot \boldsymbol{P}_{i+1} \cdot \boldsymbol{\Gamma}_{k+i}\right]^{-1} . \\
& \boldsymbol{\Gamma}_{k+i}^{T} \cdot \boldsymbol{P}_{i+1} \cdot \boldsymbol{\Phi}_{k+i}+\boldsymbol{\Phi}_{k+i}^{T} \cdot \boldsymbol{P}_{i+1} \cdot \boldsymbol{\Phi}_{k+i} \\
& \underline{g}_{i}=\left[\boldsymbol{\Phi}_{k+i}^{T}-\boldsymbol{\Phi}_{k+i}^{T} \boldsymbol{P}_{i+1} \boldsymbol{\Gamma}_{k+i}\left(\boldsymbol{R}_{i}+\boldsymbol{\Gamma}_{k+i}^{T} \boldsymbol{P}_{i+1} \boldsymbol{\Gamma}_{k+i}\right)^{-1} \boldsymbol{\Gamma}_{k+i}^{T}\right] . \\
& {\left[2 \boldsymbol{P}_{i+1} \boldsymbol{\Gamma}_{k+i} \underline{u}_{k+i-1}+\underline{g}_{i+1}\right]-2 \cdot \boldsymbol{C}_{k+i}^{T} \boldsymbol{Q}_{i} \underline{z}_{k+i},}
\end{aligned}
$$


amelynek megoldása teljesíti a következő végfeltételeket:

$$
\begin{aligned}
& \boldsymbol{P}_{N}=\boldsymbol{C}_{k+N}^{T} \cdot \boldsymbol{F} \cdot \boldsymbol{C}_{k+N} \\
& \underline{g}_{N}=-2 \cdot \boldsymbol{C}_{k+N}^{T} \boldsymbol{F} \underline{z}_{k+N}
\end{aligned}
$$

Meg kell jegyeznünk, hogy ez a szakaszos szaggatott müködésü optimális követőszabályozás könnyen és az esetek többségében valós időben implementálható algoritmust eredményez. Az algoritmus sajátossága az, hogy a kiszámított vezérlőjel-szekvencia első értékét használjuk, majd a rendszer válaszát követően ezt a szekvenciát újraszámítjuk úgy, hogy a horizontot elcsúsztatjuk. Használatát csak a kimenetre, a vezérlőjelre és az állapotokra vonatkoztatott erős korlátok befolyásolják. Ebben az esetben használjuk az ún. modell alapú prediktív irányítást (MPC-Model Predictive Control).

Ezt a módszert egyébként az optimális irányítás egyik általánosításának tekinthetjük, ha az állapotvektorra, a vezérlöjel vektorára, valamint a kimenetre valamilyen erős korlátot fogalmazunk meg. Az erős korlát olyan megszorítást jelent, amelyet semmi módon nem szabad átlépni, azaz mindig be kell tartani. Feltételezzük, hogy az állapotvektor minden elemét mérhetjük, tehát a kimenet $\underline{\tilde{x}}_{k / k}=\underline{x}_{k}=\underline{y}_{k} \quad(\mathrm{azaz}$ $\boldsymbol{C}=\boldsymbol{I})$. Továbbá feltételezzük, hogy sem a kimenetet, sem az így meghatározott állapotvektort nem terheli zaj. Ekkor természetesen nincs szükségünk az állapotvektor becslésére, mert minden az irányítási algoritmushoz szükséges információ mérhető. Felírjuk az $N$ mintavételre előre számított állapotok értékeit, mint:

$$
\begin{aligned}
& \underline{x}_{k+1 / k}=\boldsymbol{\Phi} \cdot \underline{x}_{k}+\boldsymbol{\Gamma} \cdot \underline{u}_{k / k} \\
& \underline{x}_{k+2 / k}=\boldsymbol{\Phi} \cdot \underline{x}_{k+1 / k}+\boldsymbol{\Gamma} \cdot \underline{u}_{k+1 / k}= \\
& =\boldsymbol{\Phi}^{2} \cdot \underline{x}_{k}+\boldsymbol{\Phi} \cdot \boldsymbol{\Gamma} \cdot \underline{u}_{k / k}+\boldsymbol{\Gamma} \cdot \underline{u}_{k+1 / k} \\
& \vdots \\
& \underline{x}_{k+N / k}=\boldsymbol{\Phi} \cdot \underline{x}_{k+N-1 / k}+\boldsymbol{\Gamma} \cdot \underline{u}_{k+N-1 / k}= \\
& =\boldsymbol{\Phi}^{N} \cdot \underline{x}_{k}+\boldsymbol{\Phi}^{N-1} \cdot \boldsymbol{\Gamma} \cdot \underline{u}_{k / k}+\ldots+\boldsymbol{\Gamma} \cdot \underline{u}_{k+N-1 / k}
\end{aligned}
$$

$\mathrm{Az} \underline{u}_{k / k}=\underline{u}_{k-1}+\Delta \underline{u}_{k / k}$ vezérlöjelet a $t_{k}$ mintavételt követően kell az irányított rendszer bemenetére juttatni. Az irányítás vezérlöjelét a $t_{k}, t_{k+1}, \ldots, t_{k+N_{c}-1}$ mintavételi pillanatokban a vezérlési horizontig frissítjük, ezután állandó értéken tartjuk, azaz $\underline{u}_{k+j / k}=\underline{u}_{k+N_{c}-1}$, ha $N_{c}<j<N-1$. Ez valójában az ún. vezérlési horizont. $\mathrm{Az}$ MPC megoldása lényegében a $\Delta \underline{u}_{k+j / j}$ értékek meghatározását jelenti a $\underline{u}_{k+j / k}$ helyett. Ekkor a $\Delta \underline{u}_{k+j / k}=\underline{u}_{k+j / k}-\underline{u}_{k+j-1 / k}$, és amennyiben a $t_{k}$ időpontban ismerjük az $\underline{u}_{k-1}$, értékét, akkor:

$$
\begin{aligned}
& \underline{u}_{k / k}=\underline{u}_{k / k}+\underline{u}_{k-1} \\
& \underline{u}_{k+1 / k}=\underline{u}_{k+1 / k}+\underline{u}_{k / k}+\underline{u}_{k-1} \\
& \vdots \\
& \underline{u}_{k+N_{c}-1 / k}=\underline{u}_{k+N_{c}-1 / k}+\ldots+\underline{u}_{k / k}+\underline{u}_{k-1}
\end{aligned}
$$

Az $\underline{y}$ kimeneteket megkapjuk, mint:

$$
\underline{y}_{k+j / k}=\underline{x}_{k+j / k}
$$

ahol $j=\overline{1, N}$. Az optimális vagy gyenge korlátos MPC irányítás célfüggvényét hasonló módon határozzuk meg mint az előzőkben. 


$$
\begin{aligned}
& J\left(\underline{u}^{,} \underline{x}_{k}\right)=\left\|\underline{Y}_{k}-\underline{Z}_{k}\right\|_{Q}^{2}+\left\|\underline{\Delta} \underline{U}_{k}\right\|_{\boldsymbol{R}}^{2}= \\
& =\sum_{i=1}^{N}\left(\left(\begin{array}{l}
\underline{y}_{k+i / k}-\underline{z}_{k+i / k} \\
+\Delta \underline{u}_{k+i / k}^{T} \cdot \mathbf{R} \cdot \mathbf{R} \cdot\left(\underline{y}_{k+i / k}-\underline{u}_{k+i / k}\right.
\end{array}\right)+\right)
\end{aligned}
$$

A következő jelöléseket használtuk:

$$
\begin{aligned}
& \underline{Y}_{k}=\left[\begin{array}{c}
\underline{y}_{k+1 / k} \\
\vdots \\
\underline{y}_{k+N / k}
\end{array}\right], \underline{Z}_{k}=\left[\begin{array}{c}
\underline{z}_{k+1 / k} \\
\vdots \\
\underline{z}_{k+N / k}
\end{array}\right], \\
& \Delta \underline{U}_{k}=\left[\begin{array}{c}
\Delta \underline{u}_{k / k} \\
\vdots \\
\Delta \underline{u}_{k+N_{c}-1 / k}
\end{array}\right]
\end{aligned}
$$

Az $\mathrm{N}$ iterációra érvényes $\boldsymbol{Q}$ és $R$ súlyzómátrixok a következő alakban írhatók fel:

$$
\begin{aligned}
\boldsymbol{Q} & =\left[\begin{array}{cccc}
\boldsymbol{Q}_{1} & 0 & \ldots & 0 \\
0 & \boldsymbol{Q}_{2} & \ldots & 0 \\
\vdots & \vdots & \ddots & \vdots \\
0 & 0 & \ldots & \boldsymbol{Q}_{N}
\end{array}\right] \\
\boldsymbol{R} & =\left[\begin{array}{cccc}
\boldsymbol{R}_{0} & 0 & \ldots & 0 \\
0 & \boldsymbol{R}_{1} & \ldots & 0 \\
\vdots & \vdots & \ddots & \vdots \\
0 & 0 & \ldots & \boldsymbol{R}_{N_{c}-1}
\end{array}\right]
\end{aligned}
$$

Amennyiben az $\underline{Y}_{k}$ azonos az $N$ iterációra felírt állapotvektorral, úgy a rendszer müködését leíró egyenlet [6]:

$$
\underline{Y}_{k}=\left|\boldsymbol{\Phi}^{i}\right| \cdot x_{k}+\left\lfloor\boldsymbol{\Phi}^{i} \boldsymbol{\Gamma}\right] \cdot u_{k-1}+\boldsymbol{G}_{y} \cdot \Delta \underline{U}_{k},
$$

$$
\text { ahol }\left[\boldsymbol{\Phi}^{i}\right]=\left[\begin{array}{c}
\boldsymbol{\Phi} \\
\boldsymbol{\Phi}^{2} \\
\vdots \\
\boldsymbol{\Phi}^{\mathbf{N}}
\end{array}\right] \cdot \underline{x}_{k},\left[\boldsymbol{\Phi}^{i} \boldsymbol{\Gamma}\right]=\left[\begin{array}{c}
\boldsymbol{\Gamma} \\
\boldsymbol{\Phi} \cdot \boldsymbol{\Gamma}+\boldsymbol{\Gamma} \\
\vdots \\
\sum_{\mathbf{i}=\mathbf{0}}^{\mathbf{N}} \boldsymbol{\Phi}^{\mathbf{i}} \cdot \boldsymbol{\Gamma}
\end{array}\right]
$$

$$
\boldsymbol{G}_{y}=\left[\begin{array}{ccc} 
& & \\
\boldsymbol{\Gamma} & \cdots & 0 \\
\vdots & \cdots & 0 \\
\sum_{i=0}^{N_{c}} \boldsymbol{\Phi}^{i} \boldsymbol{\Gamma} & \ddots & \boldsymbol{\Phi} \boldsymbol{\Gamma}+\boldsymbol{\Gamma} \\
\vdots & \vdots & \vdots \\
\sum_{i=0}^{N-1} \boldsymbol{\Phi}^{i} \boldsymbol{\Gamma} & \ldots & \sum_{i=0}^{N-N_{c}} \boldsymbol{\Phi}^{i} \boldsymbol{\Gamma}
\end{array}\right]
$$

A számítások szempontjából előnyös a $J\left(\underline{u}, \underline{x}_{k}\right)$ célfüggvény számítására egy $\underline{E}_{k}$ hibavektort (55) használni.

$$
\underline{E}_{k}=\underline{Z}_{k}-\left[\begin{array}{c}
\boldsymbol{\Phi} \\
\boldsymbol{\Phi}^{2} \\
\vdots \\
\boldsymbol{\Phi}^{\mathbf{N}}
\end{array}\right] \cdot \underline{x}_{k}-\left[\begin{array}{c}
\boldsymbol{\Gamma} \\
\boldsymbol{\Phi} \cdot \boldsymbol{\Gamma}+\boldsymbol{\Gamma} \\
\vdots \\
\sum_{\mathbf{i}=\mathbf{0}}^{\mathbf{N}} \boldsymbol{\Phi}^{\mathbf{i}} \cdot \boldsymbol{\Gamma}
\end{array}\right] \cdot \underline{u}_{k-1}(
$$

Ennek a lényege az, hogy az $\underline{E}_{k}$ hibavektor nem függ az aktuális mintavételektől, hanem csak az aktuális horizont kezdöértékeinek számító $\underline{x}_{k}$, illetve $\underline{u}_{k-1}$ értékektől. Ezt az $\underline{E}_{k}$ hibavektort egyébként úgy is tekinthetjük mint a követési hibát, mert ez az elöírt pálya, illetve a rendszer aktuális vezérlőjellel számított kimenete közti eltérést jelzi.

$$
\begin{aligned}
& J\left(\underline{u}, \underline{x}_{k}\right)=\Delta \underline{U}_{k}{ }^{T} \cdot\left[\boldsymbol{G}_{y}{ }^{T} \cdot \boldsymbol{Q} \cdot \boldsymbol{G}_{y}+\boldsymbol{R}\right] \cdot \Delta \underline{U}_{k}-(56) \\
& -2 \cdot \underline{E}_{k}{ }^{T} \boldsymbol{Q} \cdot \boldsymbol{G}_{y} \cdot \Delta \underline{U}_{k}+\underline{E}_{k}{ }^{T} \cdot \boldsymbol{Q} \cdot \underline{E}_{k} .
\end{aligned}
$$

Tehát a célfüggvény négyzetes alakja:

$$
J\left(\underline{u}, \underline{x}_{k}\right)=\frac{1}{2} \Delta \underline{U}_{k}^{T} \cdot \boldsymbol{H} \cdot \Delta \underline{U}_{k}+\boldsymbol{f}^{T} \cdot \Delta \underline{U}_{k}+p_{0}
$$

ahol:

$$
\begin{aligned}
& \boldsymbol{H}=2 \cdot\left[\boldsymbol{G}_{y}{ }^{T} \cdot \boldsymbol{Q} \cdot \boldsymbol{G}_{y}+\boldsymbol{R}\right], \\
& \underline{\boldsymbol{f}}=-2 \cdot \boldsymbol{G}_{y}{ }^{T} \cdot \boldsymbol{Q} \cdot \underline{E}_{k}
\end{aligned}
$$

Ennek a négyzetes kritériumnak a minimális értékét kell meghatároznunk a 
$\Delta \underline{U}_{k}$ függvényében. Ez egy szabványos optimumkeresési feladat, melyet kvadratikus programozásnak is nevezünk, amelyhez különböző egyenlőség- és egyenlőtlenségkorlátokat is rendelhetünk. Amennyiben a fenti célfüggvény korlát nélküli, vagy a szakirodalomban használt gyenge korlátos minimumát keressük, úgy ezt könnyen megkapjuk, mint:

$$
\begin{aligned}
& \frac{\partial J\left(\underline{u}, \underline{x}_{k}\right)}{\partial \Delta \underline{U}_{k}}=\frac{1}{2}\left(\boldsymbol{H}+\boldsymbol{H}^{T}\right) \cdot \Delta \underline{U}_{k}{ }^{*}+\underline{f}=\underline{0} \\
& \Delta \underline{U}_{k}{ }^{*}=\left(\boldsymbol{G}_{y}{ }^{T} \cdot \boldsymbol{Q} \cdot \boldsymbol{G}_{y}+\boldsymbol{R}\right)^{-1} \cdot \boldsymbol{G}_{y}{ }^{T} \cdot \boldsymbol{Q} \cdot \underline{E}_{k}
\end{aligned}
$$

A gyenge korlát fogalom itt azt jelenti, hogy sem az óhajtott követési hibára sem a vezérlőjel nagyságára, valamint változásának a nagyságára nem mondhatjuk, hogy bizonyosan nem halad meg egy adott korlátot, de amúgy ezek nagyságát a súlyzók megválasztásával befolyásolhatjuk. Mindezek alapján bizonyosan felmerül annak a kérdése, hogy amennyiben a célfüggvényt hasonló módon választjuk meg, a diszkrét optimális irányítási algoritmusnak, valamint a gyenge korlátos állapotteres MPC-nek azonos megoldása kellene legyen, hisz a két feladat teljesen azonos.

Ugyanakkor megemlítjük, hogy ezeknek a megoldásoknak csak azt a részét használjuk, mely az első lépésnek felel meg a regressziós horizont stratégiájának megfelelöen.

\section{A szakaszos szaggatott DLQR és az MPC algoritmusok eredmé- nyeinek összehasonlítása}

Ebben a paragrafusban különböző horizontok esetén bebizonyítjuk, hogy a diszkrét követő LQ szabályozó megegyezik a megfelelő, erős korlát nélküli MPC algoritmussal [7]. Elvileg itt a (39) és az (59) összefüggések azonosságát kell bemutatnunk. A számítások bonyolultsága miatt a levezetést csak $\mathrm{N}=1$ és $\mathrm{N}=2$ horizontokra végezzük el, nagyobb $\mathrm{N}$ értékek esetén csak numerikus szimulációk eredményeit közöljük.

\subsection{Az algoritmusok ellenőrzése $\mathrm{N}=1$ és $\mathbf{N}=\mathbf{2}$ horizont értékekre}

Az LQ diszkrét szabályozási algoritmusnál is csak a szabályozójel szekvencia első tagját küldjük a rendszer bemenetére. Ennek megfelelően $\mathrm{N}=1$ horizontra következő szabályozási algoritmust kapjuk:

$$
\begin{aligned}
& \Delta \underline{u}_{k+0}{ }^{*}=-\left[\boldsymbol{R}_{0}+\hat{\boldsymbol{\Gamma}}_{k+0}^{T} \cdot \hat{\boldsymbol{P}}_{1} \cdot \hat{\boldsymbol{\Gamma}}_{k+0}\right]^{-1} \cdot \boldsymbol{\Gamma}_{k+0}^{T} \cdot \ldots \\
& {\left[\hat{\boldsymbol{P}}_{1} \cdot \hat{\boldsymbol{\Phi}}_{k+0} \cdot \underline{\xi}_{k+0}+\frac{1}{2} \cdot \underline{g}_{1}\right] .}
\end{aligned}
$$

Felhasználva az 3. alfejezetben szereplő képleteket ((44),(45)), illetve a (37) képletben bevezetett jelöléseket, egylépéses horizont mellett a szabályozó jel változása a következő összefüggéssel adható meg:

$$
\begin{aligned}
& \Delta \underline{u}_{k}=-\left(\mathbf{R}_{0}+\boldsymbol{\Gamma}^{T} \cdot \mathbf{C}^{T} \cdot \mathbf{Q}_{1} \cdot \mathbf{C} \cdot \boldsymbol{\Gamma}\right)^{-1} \cdot \boldsymbol{\Gamma}^{\mathrm{T}} \cdot \mathbf{C}^{T} \cdot \mathbf{Q}_{1} \cdot \\
& \left(\mathbf{C} \cdot \boldsymbol{\Phi} \cdot \underline{x}_{k}+\mathbf{C} \cdot \boldsymbol{\Gamma} \cdot \underline{u}_{k-1}-\underline{z}_{k+1}\right)
\end{aligned}
$$

Az MPC algoritmusnál meghatározzuk az egylépéses horizontnak megfelelő mátrixokat:

$$
\begin{aligned}
& \boldsymbol{\Phi}^{*}=[\mathbf{C} \cdot \mathbf{\Phi}] \quad \boldsymbol{\Gamma}^{*}=[\mathbf{C} \cdot \boldsymbol{\Gamma}] \quad \mathbf{G}_{y}=[\mathbf{C} \cdot \boldsymbol{\Gamma}] \\
& \underline{E}_{1}=\underline{z}_{k+1}-\mathbf{C} \cdot \boldsymbol{\Phi} \cdot \underline{x}_{k}-\mathbf{C} \cdot \boldsymbol{\Gamma} \cdot \underline{u}_{k-1}
\end{aligned}
$$

Behelyettesítve ezeket az (59) összefüggésbe, (60)-nal azonos összefüggést határozhatunk meg.

Ha a horizont $\mathrm{N}=2$, akkor az LQ szabályozási algoritmus meghatározásához ugyancsak a (44) összefüggést használjuk, itt viszont a visszaszámlálás a második lépéstől kezdődik. Ennek megfelelően elvégezve a rekurzív számításokat a következő szabályozási algoritmust kapjuk:

$$
\Delta \underline{u}_{k}=\mathbf{S}^{-1} \cdot\left(\mathbf{S}_{1} \cdot \underline{x}_{k}+\mathbf{S}_{2} \cdot \underline{u}_{k-1}+\mathbf{S}_{3} \cdot \underline{z}_{k+1}+\mathbf{S}_{4} \cdot \underline{z}_{k+2}\right)
$$


ahol

$$
\begin{aligned}
& \mathbf{S}=\mathbf{R}_{0}+\boldsymbol{\Gamma}^{T} \cdot \mathbf{C}^{T} \cdot \mathbf{Q}_{1} \cdot \mathbf{C} \cdot \boldsymbol{\Gamma}+\boldsymbol{\Gamma}^{T} \cdot(\boldsymbol{\Phi}+\mathbf{I})^{T} \cdot \mathbf{C}^{T} \cdot \mathbf{Q}_{2} \cdot \ldots \\
& \cdot\left(\mathbf{I}-\mathbf{C} \cdot \mathbf{\Gamma} \cdot \mathbf{M}^{-1} \cdot \boldsymbol{\Gamma}^{T} \cdot \mathbf{C}^{T} \cdot \mathbf{Q}_{2}\right) \cdot \mathbf{C} \cdot(\boldsymbol{\Phi}+\mathbf{I}) \cdot \mathbf{\Gamma}
\end{aligned}
$$$$
\mathbf{S}_{1}=\boldsymbol{\Gamma}^{T} \cdot \mathbf{C}^{T} \cdot \mathbf{Q}_{1} \cdot \mathbf{C} \cdot \mathbf{\Phi}+\boldsymbol{\Gamma}^{T} \cdot(\boldsymbol{\Phi}+\mathbf{I})^{T} \cdot \mathbf{C}^{T} \cdot \mathbf{Q}_{2} \cdot \ldots
$$$$
\left(\mathbf{I}-\mathbf{C} \cdot \boldsymbol{\Gamma} \cdot \mathbf{M}^{-1} \cdot \boldsymbol{\Gamma}^{T} \cdot \mathbf{C}^{T} \cdot \mathbf{Q}_{2}\right) \cdot \mathbf{C} \cdot \boldsymbol{\Phi}^{2}
$$$$
\mathbf{S}_{2}=\boldsymbol{\Gamma}^{T} \cdot \mathbf{C}^{T} \cdot \mathbf{Q}_{1} \cdot \mathbf{C} \cdot \boldsymbol{\Gamma}+\boldsymbol{\Gamma}^{T} \cdot(\mathbf{\Phi}+\mathbf{I})^{T} \cdot \mathbf{C}^{T} \cdot \mathbf{Q}_{2} \cdot \ldots
$$$$
\left(\mathbf{C} \cdot \boldsymbol{\Gamma} \cdot \mathbf{M}^{-1} \cdot \boldsymbol{\Gamma}^{T} \cdot \mathbf{C}^{T} \cdot \mathbf{Q}_{2}-\mathbf{I}\right) \cdot \mathbf{C} \cdot(\boldsymbol{\Phi}+\mathbf{I}) \cdot \mathbf{\Gamma}
$$$$
\mathbf{S}_{3}=\boldsymbol{\Gamma}^{T} \cdot \mathbf{C}^{T} \cdot \mathbf{Q}_{1}
$$$$
\mathbf{S}_{4}=\boldsymbol{\Gamma}^{T} \cdot(\mathbf{\Phi}+\mathbf{I})^{T} \cdot \mathbf{C}^{T} \cdot \mathbf{Q}_{2}-\boldsymbol{\Gamma}^{T} \cdot\left(\boldsymbol{\Phi}^{T}+\mathbf{I}\right) \cdot \mathbf{C}^{T} \cdot \ldots
$$$$
\cdot \mathbf{Q}_{2} \cdot \mathbf{C} \cdot \boldsymbol{\Gamma} \cdot \mathbf{M}^{-1} \cdot \boldsymbol{\Gamma}^{T} \cdot \mathbf{C}^{T} \cdot \mathbf{Q}_{2}
$$

$$
\mathbf{M}=\mathbf{R}_{1}+\boldsymbol{\Gamma}^{T} \cdot \mathbf{C}^{T} \cdot \mathbf{Q}_{2} \cdot \mathbf{C} \cdot \boldsymbol{\Gamma}
$$

Az MPC algoritmusnál meghatározzuk a két lépéses horizontnak megfelelő mátrixokat:

$$
\begin{aligned}
& \boldsymbol{\Phi}^{*}=\left[\begin{array}{l}
\mathbf{C} \cdot \boldsymbol{\Phi} \\
\mathbf{C} \cdot \boldsymbol{\Phi}^{2}
\end{array}\right] \quad \boldsymbol{\Gamma}^{*}=\left[\begin{array}{l}
\mathbf{C} \cdot \boldsymbol{\Gamma} \\
\mathbf{C} \cdot(\boldsymbol{\Phi}+\mathbf{I}) \cdot \boldsymbol{\Gamma}
\end{array}\right] \\
& G_{y}=\left[\begin{array}{cc}
\mathbf{C} \cdot \boldsymbol{\Gamma} & 0 \\
\mathbf{C} \cdot(\boldsymbol{\Phi}+\mathbf{I}) \cdot \boldsymbol{\Gamma} & \mathbf{C} \cdot \boldsymbol{\Gamma}
\end{array}\right] \\
& \underline{E}_{k}=\left(\begin{array}{c}
\underline{z}_{1}-\mathbf{C} \cdot \boldsymbol{\Phi} \cdot \underline{x}_{k}-\mathbf{C} \cdot \boldsymbol{\Gamma} \cdot \underline{u}_{k-1} \\
\underline{z}_{2}-\mathbf{C} \cdot \boldsymbol{\Phi}^{2} \cdot \underline{x}_{k}-\mathbf{C} \cdot(\boldsymbol{\Phi}+\mathbf{I}) \cdot \boldsymbol{\Gamma} \cdot \underline{u}_{k-1}
\end{array}\right)
\end{aligned}
$$

A szabályozó jel kiszámításához szükségünk van a $\mathbf{H}=\left(\mathbf{G}_{v}^{T} \cdot \mathbf{Q} \cdot \mathbf{G}_{v}+\mathbf{R}\right)$, illetve az $\mathbf{L}=\mathbf{G}_{y}^{T} \cdot \mathbf{Q} \cdot \mathbf{E}_{k} \quad$ mátrixok kiszámításához. Jelöljük ezeknek a mátrixoknak megfelelő almátrix elemeit Hi.j, illetve Li -vel. Ebben az esetben felírhatjuk:

$$
\left(\begin{array}{ll}
\mathbf{H}_{11} & \mathbf{H}_{12} \\
\mathbf{H}_{21} & \mathbf{H}_{22}
\end{array}\right) \cdot\left(\begin{array}{c}
\Delta \underline{u}_{k} \\
\Delta \underline{u}_{k+1}
\end{array}\right)=\left(\begin{array}{l}
\mathbf{L}_{1} \\
\mathbf{L}_{2}
\end{array}\right)
$$

Megoldva a kapott egyenletrendszert az első lépésnek megfelelő szabályozási jel növekménye:

$$
\begin{aligned}
& \Delta \underline{u}_{0}=\left(\mathbf{H}_{11}-\mathbf{H}_{12} \cdot \mathbf{H}_{22}^{-1} \cdot \mathbf{H}_{21}\right)^{-1} \\
& \cdot\left(\mathbf{L}_{1}-\mathbf{H}_{12} \cdot \mathbf{H}_{22}^{-1} \cdot \mathbf{L}_{2}\right)
\end{aligned}
$$

Meghatározva a $\mathrm{H}$ és $\mathrm{L}$ mátrixokat és behelyettesítve a (68) összefüggésbe a (63) és (64) képletekkel azonos összefüggésekhez jutunk.

\subsection{Alkalmazási példák}

Legyen a következő egyszerü diszkrét rendszer:

$$
\left\{\begin{array}{l}
x_{k+1}=x_{k}+u_{k} \\
y_{k}=x_{k}
\end{array}\right.
$$

és adott egy lineáris kvadratikus kritériumfüggvény, ahol $\mathrm{N}=15$, a súlyozók $\mathrm{R} 0=\mathrm{R} 1$ $=1$ és $\mathrm{Q} 1=\mathrm{Q} 2=10$.

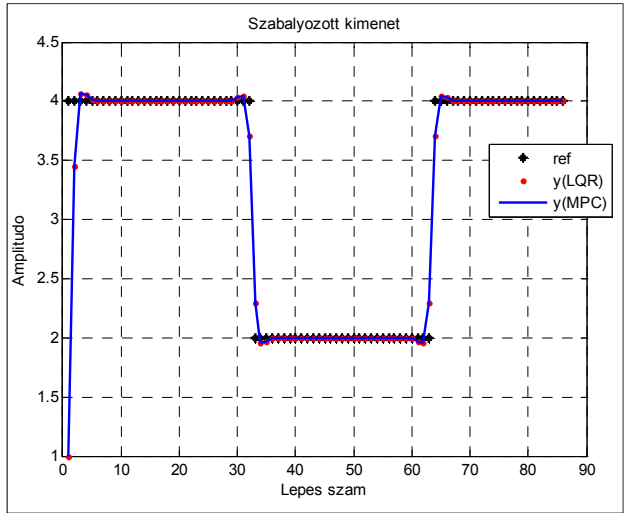

5. ábra $A z L Q R$ és $M P C$ szabályozási eredménye $N=10$ horizontra

A feladat LQR és MPC szabályozási algoritmusát a fenti módszerekkel meghatározva az 5. és 6 . ábrákon megjelenített szimulációs eredményeket kapjuk. Mivel a két módszer eredménye nagyon hasonló, ezért a 7. ábrán kinagyítva ábrázoltuk a különböző módon számított szabályozó jelek közötti eltérést. 


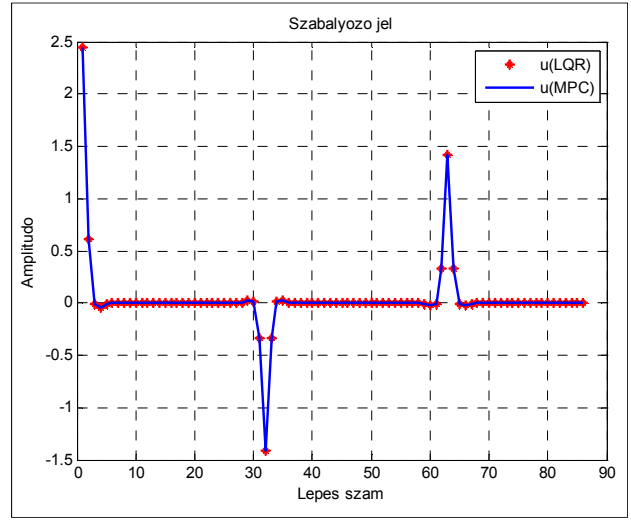

6. ábra $A z L Q R$ és $M P C$ módszerekkel számitott szabályozó jelek

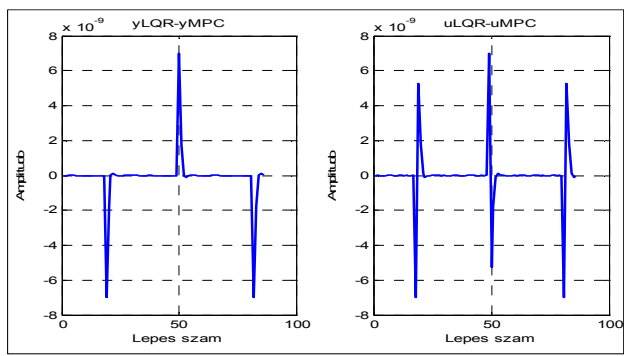

7. ábra $A z L Q R$ és MPC módszerekkel számított szabályozó jelek és szabályozott jelek közötti eltérés

\section{Következtetések}

A dolgozat az állapotfüggő Riccatiegyenleteken alapuló irányítási módszerek felhasználásának kérdését tárgyalja nemlineáris rendszerek esetében, rámutatva az így kapott szuboptimális eljárás hibaforrásaira. A tanulmány része a csúszó horizontú DLQR inkrementális szabályozási algoritmusok különböző változatainak a tárgyalása, illetve a diszkrét lineáris, véges horizon- tú szabályozás összehasonlítása a nem korlátos modell alapú prediktív szabályozással. Az általános következtetéseket számítási és Matlab $^{\circledR}$ szimulációs példák támasztják alá.

\section{Szakirodalmi hivatkozások}

[1] Bitmead, R.R., Gevers, M.: Riccati Difference and Differential Equations: Stabilizability, Convergence, Monotonicity in The Riccati Equation in Control, Systems and Signals. S. Bittanti, A.J. Laub and J.C. Willems (eds), Springer-Verlag, Berlin, 1991. 263-291 oldal.

[2] Cloutier, J. R., D’Souza, C. N., Mracek, C. P.: Nonlinear regulation and nonlinear $\mathrm{H}$ infinity control via the state-dependent Riccati equation technique: Part 1, Theory, Part 2, Examples. In: Proceedings of the International Conference on Nonlinear Problems in Aviation and Aerospace, Daytona Beach, FL, May 1996.

[3] Erdem, E.B., Alleyne, A.G.: Globally Stabilizing Second Order Nonlinear Systems by SDRE Control. Proceedings of the American Control Conference, San-Diego, California, June, 1999. 2501-2505.

[4] Cloutier, J.R., Stansbery, D.T., Sznaier, M.: On the recoverability of nonlinear state feedback laws by extended linearization techniques. In: Proc. of the American Control Conference, San Diego, CA 1999. 1515-1519.

[5] Dávid L., Tehnici de optimizare. Petru-Maior Egyetemi Kiadó, Marosvásárhely, 2000.

[6] Camacho, E.F.: Model Predictive Control. Ed. Springer, 2004.

[7] György, K., Dávid, L.: A nem korlátos MPC és véges horizontú diszkrét $L Q R$ algoritmusok összehasonlitása. XIX Számokt Nemzetközi Számítástechnika Konferencia, 2009. Târgu Mureş, 220-226. 